\title{
Can Regulation of Insider Trading Be Effective?
}

\author{
Alexandre Padilla*
}

\begin{abstract}
While there is a very prolific literature showing that the regulation of insider trading is by and large ineffective when it comes to discourage individuals from trading on non-public information, almost no work has been done on whether insider trading regulation can be effective. This paper attempts to fill that gap by investigating whether the regulation of insider trading can be effective. First, we show why insider trading regulation cannot be effective. Second, we see to what extend the empirical studies are consistent with our analysis.
\end{abstract}

JEL classification: D820, G380, K220.

Keywords: Information; Insider Trading; Government Regulation, Strategic Decisions.

* Alexandre Padilla (B.S. Economics 1996, M.A. Economics 1997, and Ph.D. Economics 2003, University of Law, Economics, and Science of Aix-Marseille III, Aix-en-Provence, France) is Assistant Professor of Economics at the Metropolitan State College of Denver. Contacting Author Information: Metropolitan State College of Denver, Department of Economics, Campus Box 77, P.O. Box 173362, Denver, CO 80217-3362 Tel. 303-556-3131; fax: 303-556-3966.

Email address: padilale@mscd.edu (Alexandre Padilla) 


\title{
Can Regulation of Insider Trading Be Effective?
}

\begin{abstract}
While there is a very prolific literature showing that the regulation of insider trading is by and large ineffective when it comes to discourage individuals from trading on non-public information, almost no work has been done on whether insider trading regulation can be effective. This paper attempts to fill that gap by investigating whether the regulation of insider trading can be effective. First, we show why insider trading regulation cannot be effective. Second, we see to what extend the empirical studies are consistent with our analysis.
\end{abstract}

JEL classification: D820, G380, K220.

Keywords: Information; Insider Trading; Government Regulation, Strategic Decisions. 


\section{Introduction}

This paper investigates whether the regulation of insider trading or insider trading laws can be effective. ${ }^{1}$ Following Henry Manne's publication of Insider Trading and the Stock Market, the debate surrounding the question of insider trading and whether or not it should be regulated has received a lot of attention from lawyers, economists, and financiers and a prolific literature has ensued. One particular aspect of the debate was centered on the question of whether the regulation of insider trading or insider trading laws are effective. Indeed, with the evolution of insider trading laws, students of insider trading laws have attempted to see whether these laws are effective in discouraging insiders from trading on non-public information. Whether they focus on insider trading in general or insider trading around particular corporate events, by and large, the consensus

\footnotetext{
${ }^{1}$ We use the standard definition of insider trading adopted in the literature, which is the use of material nonpublic information about a corporation in a securities transaction. Insiders are traditionally defined as any individual who has access or has been given access to inside information. The American legislation uses the same definition of insider trading. However, it introduces a distinction within the class of insiders by differentiating registered (inside) insiders from (unregistered) outside insiders (tippees). Registered insiders (or corporate insiders) are defined by the Section 16 of the Securities Exchange Act of 1934 as every director and officer of the corporation plus any owners of more than $10 \%$ of the corporation's equity. They are required by the Section 16(a) to report periodically all their trade in equity securities to the SEC. Unregistered insiders (or outside-insiders) are also in possession of material nonpublic information but are not required to report their transactions to the SEC. Unregistered insiders' acquisition of inside information can be direct in the course of their work (investment bankers, lawyers, risk arbitragers, accountants, financial printers) or indirect by the intermediary of registered insiders (tippees).
} 
was almost unanimous: insider trading laws are ineffective, they are unsuccessful in deterring insiders from trading on non-public information.

Although these empirical studies reveal very informative and can provide interesting and illustrative evidence regarding the ineffectiveness of regulation, these studies are not useful if one wants to make a case against the government-enforced regulation of insider trading based on its effectiveness simply because none of these studies investigate the causes of such ineffectiveness. Actually, the only conclusion that one can derive from this empirical literature is that government regulation of insider trading is ineffective. However, the fact that the empirical literature shows that government regulation of insider trading has been so far ineffective cannot be interpreted as showing that government regulation cannot be effective and, therefore, should be repealed.

Another problem is that, even outside the empirical literature, almost no systematic research on this issue has been conducted. ${ }^{2}$ Therefore, the contribution of this paper is to fill that gap. In this paper, we will investigate whether regulation can be effective in deterring insiders from trading on inside information. ${ }^{3}$ We will show in this paper that there is a theoretical as well as practical impossibility for government regulation of insider trading to be effective in deterring insiders from trading on inside information.

\footnotetext{
${ }^{2}$ An exception is Matthew Spiegel and Avanidhar Subrahmanyam, The Efficacy of Insider Trading Regulation, Working Paper 257, Berkeley, University of California, Institute of Business and Economic Research (1995). However, we shall see, their argument is incomplete.

${ }^{3}$ Another justification for investigating whether insider trading regulation can be effective is the fact that most advocates of insider trading regulation by and large seem to assume cannot fail. See Jhinyoung Shin, The Optimal Regulation of Insider Trading, 5 J. Fin. Econ. 49 (1996) and Arturo Bris, Do Insider Trading Laws Work? Yale ICF Working Paper No. 00-19, 2 n. 4 (2000).
} 
First, we discuss whether the regulation of insider trading can be effective. Second, we will show to what extend our analysis is consistent with the empirical literature. Finally, we will offer some concluding remarks.

\section{Can the regulation of insider trading effective?}

In this section, we investigate whether regulation can be effective in deterring insiders from trading on inside information. We show in this section that there is a theoretical as well as practical impossibility for government regulation of insider trading to be effective in deterring insiders from trading on inside information.

\subsection{Intangibility, First Accessing Person, and Information Network}

In order to understand the problems faced by the regulator, we need to understand insider trading laws' main objective. The regulation of insider trading prohibits insiders from using inside information in securities transaction decisions. In other words, the main objective of the regulator is to prevent nonpublic information from circulating in the stock markets. In attempting to do so, the regulator faces various problems that are related to the nature of the good which he or she attempts to control: information.

The first problem the regulatory authority must face is that information is an intangible good. Therefore, compared to a physical good, no physical barrier can prevent it from flowing and circulating. It can be argued that information can be prevented from circulating or even being used as soon as it has been embodied in a piece of paper such as a note or a memorandum. Therefore, the argument goes, the insider who has access to the materialized information and could trade on it is going to refrain from doing so because she would be under greater scrutiny. 
While this might be true, the regulator will still be confronted with an additional problem. Even if the insider refrains from trading on inside information, nothing prevents her from communicating it to a third party. To circulate, there is no need for the information to be under a tangible form. As soon as the insider has access to the information, there is no way to know whether she has communicated what she knows to a third party insofar as she did not transmit the information in its materialized aspect. In other words, the regulator faces a "first accessing person" problem, that is, there is always a first person who has access to the information. As a consequence, even if this person is under great scrutiny, the regulator is confronted with an additional problem. He cannot prevent this person from communicating this information to a third party except by prohibiting this person from accessing the information, which is impossible because that would mean prohibiting her from performing her job.

This problem of a first accessing person aggravates when there is more than one person with access to the information. In the corporation, more than a few people have access to inside information; there is a myriad of individuals who come across confidential information on a regular basis in the course of their duties. Moreover, some of these individuals are not directly employed by the corporation; they work on a temporary basis for the corporation and yet have access to inside information. ${ }^{4}$ As the

\footnotetext{
${ }^{4}$ See, for example, Chiarella v. United States, 445 U.S. 222 (1980), United States v. O'Hagan, 521 U.S. 642 (1997), and United States v. Willis, 737 F. Supp. 269 (S.D.N.Y. 1990) cases, where the persons charged in violation of Section 10(b) of the Securities Exchange Act of 1934 and the Securities Exchange Commission 10b-5 were not directly employed by the corporation where the confidential information had been produced.
} 
number of people accessing confidential information increases, the number of third parties with access to information increases as well.

Moreover, the regulator's problem does not stop at the level of third parties. Third parties can also communicate the indirectly acquired information to other parties which themselves can communicate this information to other parties. ${ }^{5}$ The network by which the information circulates can become very complex and the higher the degree of complexity of the network, the greater the difficulty for the regulator to prevent the information from circulating. Also the regulator will have problems tracing back the information to its source. This latter condition is necessary if the regulatory authority wants to eliminate illegal insider trading and deter individuals from trading on the basis of inside information. The effectiveness of a regulation relies upon its effectiveness to prevent first accessing individuals from communicating inside information to third parties. In other words, to be effective the regulation of insider trading must attack the problem at its source, that is, the first individuals who have access to inside information.

Finally, the more complex the network through which the information flows, the more distorted the information is going to be. In other words, because individuals have different interpretation and different ways of communicating the information, the

\footnotetext{
${ }^{5}$ Sometimes, they may communicate the information even without knowing they are doing so. The author would like to thank Professor Steven Call for drawing his attention to this point. See, for example, SEC v. Switzer, 590 F. Supp. 756 (W.D. Okla. 1984): George Platt, Phoenix's CEO and, therefore, an insider in regard to Phoenix, discussing with his wife about a recent business trip to New York at a track meet, inadvertently communicated inside information to Coach Switzer who laid down a on a row of bleachers behind them; inside information that he later used to buy a substantial number of Phoenix shares and tipped off a number of his friends.
} 
information progressing through the network is going to be subject to transformations. The further the information goes into the network, the more likely the information is going to be different from its original form. As a consequence, even if the regulator has been able to detect a potential illegal transaction based on inside information, he still has to identify what the inside information is on which the potential malefactor has based her transaction.

The problem we have just discussed is not totally new. Our analysis is reminiscent of the analysis that we find in the economics of prohibition and the consequences that prohibition entails, that is, the emergence of illegal parallel, or black, markets as a mechanism to circumvent the regulation. Manne already described this phenomenon of illegal markets for inside information. ${ }^{6}$

We now turn to another problem the regulator must face: the inefficacy of the mechanism of detection for illegal insider trading. This problem is also due to the intangible nature of non-public information.

\subsection{Circumstantial Evidence, Subjectivism, and Strategic Behaviors}

Meulbroek (1992) explains that regulatory authorities (such as the SEC) use a multipronged strategy to detect and prosecute illegal insider trading. ${ }^{7}$ The first source comes from individuals informing on other people. The other source relies upon tangible evidence ("a smoking gun") such as notes, memoranda, or telephone conversations which indicate that an investor traded on the basis of inside information. The last strategy relies on circumstantial, or statistical, evidence to detect and prosecute insiders.

\footnotetext{
${ }^{6}$ See Henry Manne, Insider Trading and the Stock Market 59-75 (1966).

${ }^{7}$ See Lisa K. Meulbroek, An Empirical Analysis of Illegal Insider Trading, 47 J. Fin. 1661 (1992)
} 
The SEC usually lacks hard evidence due to the intangible nature of inside information. As a consequence, it relies often only on circumstantial evidence to detect and prosecute illegal insider trading. ${ }^{8,9}$ The use of circumstantial evidence, that is, of

${ }^{8}$ Id. at 1680 . Meulbroek also documents that $41 \%$ of all insider trading investigations are triggered on the basis of information provided by informants. In the Insider Trading and Securities Fraud Enforcement Act of 1988 (See Insider Trading and Securities Enforcement Act of 1988, November 19, 1988, P.L. 100-704, Sec 21A (e), H.R. 5133.), the Congress gives authority to the SEC to award bounties to informants who provides information leading to the recovery of a civil penalty from an insider, from a person who tipped information to an insider, or from a person who controlled directly or indirectly an insider. Moreover, this bounty program allows the SEC to give up to $10 \%$ of the civil penalty recovered by the SEC or the Attorney General. While the SEC does rely also on such a mechanism to prosecute insider trading, there is no empirical available evidence that such a program has leaded to an increase in the number of successful indictments or a decrease in insider trading. It is also difficult to appreciate to what extent such a program can be effective in deterring insider trading insofar as one principal consequence of such a program is that most of the informants will use such a mechanism in order to pursue a different goal mainly related to revenge or envy in the same way that tax evasion investigations are triggered on information provided by angry wives or jealous neighbors. It is therefore difficult to asses the effectiveness of such a mechanism.

${ }^{9}$ SEC John Chad made at several occasions clear that many insider trading prosecutions rely on statistical evidence. For example, when asked during the 1983 Congressional Hearings whether the SEC could have successfully prosecuted a particular case if the standard of proof for an insider trading conviction was raised, he answer "it would be difficult, because that case, like most of these cases, was built on circumstantial evidence" (Insider Trading Sanctions and SEC Enforcement Legislation. Hearing before the Subcommittee on Telecommunications, Consumer Protection, and Finance. 98th Congress. First Session on H.R. 559. April 13, 1983. Serial Number 98-33: p. 61.) Another example comes from a SEC memorandum from Office of the General Counsel to Chairman John Shad (1983), in the SEC expresses its concern about the idea of raising the burden of proof to a higher level: 
"unusual price movements on insider trading days," poses several problems that undermine the effectiveness of the regulation itself. ${ }^{10}$ Spiegel and Subrahmanyam (1995) develop an interesting model to explain "why the SEC cannot effectively use statistical

".... the burden of proof in Commission injunctive actions is proof by preponderance of evidence. Commentators have suggested that in light of the possibility of a judge imposing a higher sanction, a higher burden of proof should be required in actions seeking the proposed civil penalty.

On the other hand it should be noted that the proof in many of the Commission's insider trading cases depends heavily on circumstantial evidence. A higher burden of proof, such as a clear and convincing standard, would make it more difficult for the Commission to prove its case, particularly in insider trading cases where most cases are built on circumstantial evidence."

Examples of recent cases based on circumstantial evidence brought by the SEC and in which courts accept circumstantial evidence as an appropriate means in proving insider trading in SEC fraud cases are: US v. Mylett. Docket No. 96-1309, United States Court of Appeals for the Second Circuit. 97F.3d 663; 1996 U.S. App. LEXIS 26113; Fed. Sec. L Rep. (CCH) p. 99, 326, 1996; SEC v. Warde. Docket No. 966190. United States Court of Appeals for the Second Circuit. 151. F.3d 42; 1998 U.S. App. LEXIS 15991; Fed. Sec. L. Rep. (CCH) p. 90, 239; 49 Fed. R. Evid. Serv. (Callaghan) 1131 (1998); SEC v. Sargent. No. 00-1293. United States Court of Appeals for the First Circuit. 229 F.3d 68; 2000 U.S. App. LEXIS 25273. Fed. Sec. L. Rep. (CCH) P91, 244.55 Fed. R. Evid. Serv. (Callaghan) 1103. 2000; United States SEC v. Ginsburg. Case No. 99-8694-CIV-RYSKAMP/ VITUNAC. United States District Court for the Southern District of Florida. West Palm Beach Division.242 F. Supp. 2d 1310; 2002 U.S. Dist. LEXIS 25292. 2002; and SEC v. Franco. 01 Civ. 3872(JGK). United States District Court for the Southern District of New York. 2003. A research on LexisNexis Academic showed that 168 Federal and State Cases have been prosecuted under the basis of circumstantial evidence in the last ten years, 129 in the last five years, 48 in the last two years, 20 in the last year.

${ }^{10}$ Meulbroek, supra note 7, at 1689. 
information to identify and deter corporate insiders who may trade on material, nonpublic information."11

Before entering the details of their analysis, it is necessary to briefly explain how a mechanism to detect and prosecute insiders relying upon circumstantial evidence works. They describe the functioning of the mechanism as follows:

First, the RA [regulatory authority] establishes a rule, which stipulates that if a certain random variable (e.g., the price move during a trading day) exceeds a certain exogenous threshold, and the trader in question has traded during the day, he will be prosecuted for illegal insider trading. Second, investors obtain information and trade. Third, the RA observes the size of each investor's trade and the transaction price. The RA also observes any subsequent price changes. ... Based upon these observations, and the rule established in the first stage, the RA determines whether or not to prosecute particular individuals. ${ }^{12}$

In other words, if the trading volume of a trader is "abnormal" in comparison to his usual trading volume, if the timing of his transaction is "suspect" regarding the disclosure of a material information, or if the transaction took place prior to a significant subsequent price movement; therefore, the regulatory authority will consider that such a transaction has been realized on the basis of inside information.

Most of Spiegel and Subrahmanyam's argument is largely inspired by Lucas's work on rational expectations and his criticism of econometric models that neglect the effect of

\footnotetext{
${ }^{11}$ Spiegel and Subrahmanyam, supra note 2.

${ }^{12}$ Id. at $9-10$.
} 
agents' rational reaction to anticipated future macroeconomic policy decisions. ${ }^{13}$ When trying to detect and prosecute insiders using circumstantial evidence, the regulatory authority is faced with a major problem. Once the rule used by the regulator to detect and prosecute insiders becomes known to insiders, the insiders possessing the most accurate information are going to modify strategically their behavior to avoid investigations. ${ }^{14}$ In other words, knowing that the regulator's rule to trigger an investigation is based on price movement during a trading day exceeding a certain threshold, insiders possessing confidential information, being the most able to make more accurate estimates regarding future stock prices, are also going to be the most able to predict when the regulator is going to suspect that non-public information has been circulating and insider trading took place. Insiders with more accurate confidential information are, consequently, going to rationally adapt their trading strategy in order to avoid the stock prices reaching the threshold above which the regulator will start investigating insiders' transactions. Therefore, the argument goes, the individuals with less accurate information - being less capable to predict the magnitude of the stock price changes resulting from their transactions - will be more likely to trigger the investigations and be prosecuted on the basis of circumstantial evidence. In other words, when the regulation of insider trading relies on statistical evidence to detect and prosecute insider trading, as it is mostly the case today, the population of individuals who are going to be prosecuted will consist essentially of people who have traded on the basis of immaterial information. In

\footnotetext{
${ }^{13}$ See Robert E. Lucas, Econometric Policy Evaluations: A Critique. 1 Carnegie-Rochester Series on Public Policy 19 (1976).

${ }^{14}$ Spiegel and Subrahmanyam, supra note 2, at 27.
} 
conclusion, insider trading regulation cannot be effective. It does not discourage insiders in possession of non-public material information from trading since the quality of information they possess makes it unlikely they will be detected and prosecuted. ${ }^{15}$

There is no doubt that Spiegel and Subrahmanyam provided us with a very powerful model explaining why regulation of insider trading cannot be effective in discouraging insiders from trading on material non-public information. However, there are at least two additional considerations that should be taken into account when explaining the ineffectiveness of a regulation relying upon circumstantial evidence to detect and prosecute insider trading.

First, although the literature tends to focus on the active aspect of insider trading trading on the basis of inside information - from a technical point of view, insider trading can also take a passive form. Insider trading does not automatically imply that a securities transaction occurs. An insider trading takes place when an individual has used of information not available to the public to make a decision regarding a securities transaction. In other words, if an individual in possession of inside information decides to cancel a securities transaction, that is, not buy or sell stocks, technically, she is also liable for illegal insider trading since her decision was made on the basis of inside information. Put differently, if an individual either has avoided a loss or has realized a profit by not realizing a securities transaction and her decision was determined on her having nonpubliamaterial information, she has committed an insider trading.

Because there is no trading involved even though there is decision, this type of insider trading cannot be detected. Since the regulator relies mostly on statistical evidence

\footnotetext{
${ }^{15}$ Id. at 21.
} 
(observation of stock price changes) to detect and infer whether insider trading occurred, it is impossible for him to detect this form of insider trading for the reason that such activity simply does not involve stock price changes per se.

Another issue that deserves attention when discussing the effectiveness of regulation relying on circumstantial evidence to detect and prosecute insider trading is that information as well as inside information do not have any objectivepredictive power or objective value. Holding particular information regarding a particular corporate event does not give an individual the ability to predict with certainty the direction or magnitude of future stock price changes. Information is always subject to individuals' subjective interpretations, which vary with individuals' experiences and knowledge. ${ }^{16}$ Therefore, when individuals use information (public or not) in profit-seeking decisions, the success of their decisions does depend of the direction and magnitude of price changes. However, the latter depend on whether or not market participants interpreted the same information as they did. In other words, while insiders have technically an informational advantage by holding information not yet available to the public when they are making their decision, the success of their expectations is ultimately conditional upon the other market participants' interpretations regarding the information and resulting expectations once the non-public information has been disclosed to them. Therefore, an insider may make a transaction on the basis of inside information expecting that market participants are going

\footnotetext{
${ }^{16}$ See, for example, Ludwig M. Lachmann, Professor Shackle on Economic Significance of Time, 11 Metroeconomica (April/August 1959) rep. in Ludwig M. Lachmann, Capital, Expectations, and the Market Process: Essays on the Theory of the Market Economy at 81-93 (1977), Ludwig M. Lachmann, From Mises to Shackle: An Essay on Austrian Economics and the Kaleidic Society, 14 J.1 Econ. Lit. 54 (1976), and Ludwig M. Lachmann, The Market as an Economic Process (1986).
} 
to react in a particular way once the information is disclosed but it is possible that market participants are not going to react in the expected way. ${ }^{17}$ As a result, instead of realizing a profit or avoiding a loss as expected, the insider may perfectly realize the opposite.

The fact that information is a subjective concept and the outcome of insider's decision depends on other market participants' interpretation and resulting decisions is also an obstacle to the effectiveness of the regulation of insider trading. The resulting implication is that, while the insider has broken the law, the regulator will not receive any signal that could help him to infer that insider trading has occurred because insider's expectations regarding the reaction of market participants to the disclosure of the information were inaccurate.

17 One could argue that, while in theory our argument is true, everybody in practice as the same interpretation of the information. A typical example is that everybody will interpret a bad earnings report the same way. Actually, this is not totally true in the sense that we mean by interpretation of the information the reaction that the information is going to induce is the person who has access to it. The fact that the firm has experimented bad earnings in the past year does not mean that everybody is going to sell his shares. The reaction to a bad earnings report depends of whether shareholders interpret this bad earning report as a signal that the firm is on the downward slope in terms of performance or it is just due to a bad economic conjuncture. In the same way, a takeover announcement will not create the same reactions among shareholders. Some of them may believe that it is the takeover for diversification purposes might be a bad strategy. Others might believe that the takeover is just a mean for the acquiring management team to increase its prestige, compensation packages, perks, and so on. It is in this sense that we argue that information is always subject to individuals' subjective interpretation. See Ludwig M. Lachmann, An Austrian Stocktaking: Unsettled Questions and Tentative Answers, in Louis M. Spadaro (Ed.), New Directions in Austrian Economics, at 3-4 (1978). 


\subsection{Strategic Behavior and Liquidity}

In 1984, former SEC chairman, John Shad argued that the securities laws and, more particularly, anti-insider trading laws were at the origin of the success of U.S. securities markets:

Fifty years ago, in the depths of the depression, the nation's securities markets were demoralized. Today, they are by far the best capital markets the world has ever known - the broadest [the most liquid], the most active and efficient, and the fairest. The Securities and Exchange Commission has played an important role in the restoration of public confidence ... [and] has discharged with distinction its mandate to protect investors and maintain fair and orderly markets. ${ }^{18}$

Later, in his speech to the "SEC speaks" Conference, then-SEC chairman, Arthur Levitt restated that the SEC through the regulation of insider trading played a key role in the current success of American securities markets. He comments:

Our markets are a success precisely because they enjoy the world's highest level of confidence. Investors put their capital to work - and put their fortunes at risk because they trust that the marketplace is honest. They know that our securities laws require free, fair, and open transactions. ${ }^{19}$

It is therefore a quite accepted argument that the securities laws and, more particularly, the regulation of insider trading has largely contributed to the success of the

\footnotetext{
${ }^{18}$ See John Shad at 1 (1984) quoted in Amar Bhide, The Hidden costs of stock market liquidity, 34 J. Fin. Econ. 31, 31 (1993).

${ }^{19}$ See Arthur Levitt, A Question of Integrity: Promoting Investor Confidence by Fighting Insider Trading, Remarks of Chairman Arthur Levitt to the "SEC speaks" Conference, Washington D.C. (1998).
} 
securities markets by restoring the investor confidence by guaranteeing that they are not going to be "cheated by insiders". ${ }^{20}$ The theoretical literature tends also to argue that prohibiting insider trading would increase liquidity and decrease the cost of equity. ${ }^{21}$ This literature relies on the Akerlof's adverse-selection model to argue that the prohibition of insider trading will increase liquidity and decrease the cost of equity. ${ }^{22}$ This literature argues that, in presence of informed traders (insiders), risk-averse uninformed market participants facing the uncertainty of trading with insiders will be reluctant to invest on the market because they realize that they could be better off not trading. Therefore, this literature argues, the liquidity of the market will decrease because there is less participants on the market. This in turn poses another problem coming on the top of the adverse selection problem posed by insider trading. In illiquid markets, investors will have more difficulties to dispose of their securities on short notice. As a result, they will ask a higher risk premium under the form of a higher return on equity and a lower buy price to compensate the risks associated with illiquid markets and the possibility of trading with insiders. These costs associated with insider trading and illiquid markets are ultimately borne by the firms that see the costs of raising capital through issuing

\footnotetext{
${ }^{20}$ Id. at 7. Now, while this point is beyond the scope of this paper, one might wonder what moral implications and economic repercussions such statements by government officials may have with respect to the public and investors once we realize that insider trading laws are ineffective.

${ }^{21}$ See Lawrence R. Glosten, Insider Trading, Liquidity and the Role of the Monopolist, 62 bJ. Bus. 211 (1989); Utpal Bhattacharya and Matthew Spiegel. Insiders, Outsiders, and Market Breakdowns, 4 Rev. Fin. Stud. 255 (1991).

${ }^{22}$ See George A. Akerlof, The Market for "Lemons": Quality, Uncertainty, and the Market Mechanisms, 85 Q. J. Econ. 488 (1970).
} 
securities to the public increasing. Therefore, this literature concludes that, by prohibiting insider trading, investors will be more willing to participate and will ask a lower risk premium for the risks associated with insider trading, hence, this will lead to lower costs of raising equity for firm and more liquid markets. Bhattacharya and Daouk (2002) also provide empirical evidence showing that countries enforcing insider trading laws enjoy greater level of liquidity and lower costs of equity than countries not enforcing insider trading laws or not having insider trading laws. ${ }^{23}$

This latter fact offers another explanation why the regulation of insider trading cannot be effective. The actual regulation has created the conditions for its ineffectiveness. It has generated consequences that have modified the environment to which the regulation originally applied. In particular, by increasing the market liquidity, the regulation has

\footnotetext{
${ }^{23}$ See Utpal Bhattacharya and Hazem Daouk, The World Price of Insider Trading, 57 J. Fin. 75 (2002). However, it is important to emphasize that Bhattacharya and Daouk (at 104) are reluctant to attribute causality between enforcement of insider trading laws and liquidity and cost of equity because the first enforcement insider trading action is also related to an increase in country credit ratings. They therefore consider that, while their findings are instructive, there should be also another unobservable causal variable, namely, the attractiveness of the stock market to outside investors. There are also two factors not emphasized by the authors that may explain why investors participate more. First, insider trading laws create the illusion that there is no insider on the stock market to "cheat" the investors. Second, the rules about publications of corporate information or, more recently, prohibitions about selected disclosure, create the illusion that they are "equally informed." It is necessary to recall here that the original purpose of insider trading laws has been to place investors on a "level playing field," that is, to place investors on an equal footing for the access of information and for profit-making on the stock market. See, for example, Council Directive 89/592/ECC of 13 November 1989, coordinating regulations on insider trading in Europe. See also Arthur Levitt, supra note 19, at 2.
} 
given the ability to strategic insiders to better hide their informed trades. With more liquid markets, insiders' trades become noisier and do not show up as fast as in illiquid markets where volumes are small and unusual trades show up very fast. ${ }^{24}$ In other words, the regulation of insider trading creates the "illusion" that there is no insider trading. As a result, investors are going to participate more, believing that insiders are not going to take advantage of them. With the liquidity of the stocks increasing, the impact of insiders' informed trades are going to be diluted among investors' transactions and will not show up as clearly as they would if stocks were illiquid. As a consequence, the regulatory authority will not be able to distinguish informed trades among the large volume of transactions realized on the markets and neither will they be able to observe abnormal volume or price changes. The more liquid the markets are, the more ineffective the use of circumstantial evidence to detect illegal insider trading is.

\section{Can the regulation of insider trading be effective? The empirical evidence}

In this section, we examine whether the empirical literature findings are consistent with our previous analysis. As we will see, those studies are quite consistent with our previous analysis at two levels. First, they do show that, in general, (corporate) insiders refrain from trading around major corporate events because their transactions around those events are under greater scrutiny. On the other hand, those studies also show that insiders still make transactions based on non-public information around other corporate events as they keep realizing abnormal profits. Second, as we will show below, some studies show that there are some individuals other than registered insiders that have

\footnotetext{
${ }^{24}$ Bris, supra note 3 , at 9 .
} 
access to inside information and base their securities transactions on such information to realize abnormal profits. The results of these studies tend to confirm our description of information networks and also the fact that a large variety of individuals come across inside information more or less incidentally.

There are two types of empirical study on insider trading regulation. The first type focuses on the impact of regulation on illegal insider dealing in the aggregate. The second kind focuses on insider trading around major corporate events such as takeover or earnings announcements and analyzes the impact of regulation on insiders' trading activity around these announcements.

Before discussing these studies, it is necessary to point the data on insider trading used in these studies come from the SEC's monthly published Official Summary of Insider Trading Transactions or the Ownership Reporting System (ORS) database compiled by the SEC in which, corporate (registered) insiders' securities transactions are reported and tracked as required by Section 16(a) of the Securities Exchange Act of 1934. ${ }^{25}$ As Meulbroek observes however, because insider trading based on inside information is illegal, it is likely that these corporate insiders do not report their informed transactions, which is problematic when it comes to measure the impact of regulation on

\footnotetext{
${ }^{25}$ See supra note 1 for a definition of corporate insiders. In the ORS database, each corporate insider filing with the SEC is assigned an Insider Identifier Number. Once assigned, the SEC uses the Insider Identifier Number to track all transactions of the insider. In the ORS database are also reported among other things the nature of the ownership, the filer name and the nature of his relationship as an insider with the issuer, the security name, the issuer name, the nature of the transaction, the transaction amount, and the transaction price.
} 
illegal insider trading. ${ }^{26}$ Moreover, these studies usually do not take into account trading by unregistered (outside) insiders because they are not required to report their transactions to the SEC, which makes more difficult to identify their transactions. ${ }^{27}$ Therefore, while these studies as it will be shown offer interesting results, they largely underestimate the volume of insider trading taking place on the stock exchanges because they mostly focus on reported transactions by corporate insiders.

\subsection{How Does Insider Trading Regulation Perform Overall?}

The first type of study that we are going to discuss are studies that test how insider trading regulation perform overall in discouraging insiders from trading on inside information. Moreover, some of these studies test the impact of regulatory changes on the trading of insiders. Their starting observation is that, when insiders trade securities in their own firms, they are able to earn abnormal profits. ${ }^{28}$ This observation is in contradiction with the strong version of the efficient market hypothesis version stating that "security prices fully reflect all available information" and, accordingly, any

\footnotetext{
${ }^{26}$ Meulbroek, supra note 7.

${ }^{27}$ An exemption is Arshadi and Eyssell's study that attempts to assess insider trading by outside-insiders by utilizing a series of tests to facilitate inferences about the behavior of outside-insiders. See Nasser Arshadi, and Thomas H. Eyssell. The Law and Finance of Corporate Insider Trading: Theory and Evidence 87-117
} (1993).

${ }^{28}$ See James H. Lorie and Victor Niederhoffer, Predictive and Statistical Properties of Insider Trading, 11 J. L. \& Econ. 35 (1968); Jeffrey F. Jaffe, Special Information and Insider Trading, 47 J. Bus. 410 (1974); Joseph E. Finnerty, Insiders and Market Efficiency, 31 J. Fin. 1141 (1976); H. Nejat Seyhun, Insiders' Profits, Cost of Trading, and Market Efficiency, 16 J. Fin. Eco. 189 (1986); and Meulbroek, supra note 7. 
systematic profit opportunities are precluded..$^{29}$ Therefore, such a violation of the strong version of the efficient market hypothesis implies that not all available information is reflected in security prices, because, if it were, insiders would not be able to earn abnormal returns. ${ }^{30}$ Suchability to better predict price movements and earn abnormal returns can find its origin in the fact that insiders have access to and trade on the basis of publicly unavailable information, which is not yet reflected in security prices.

In order to measure the effectiveness of insider trading laws, these studies traditionally test two hypotheses. First, as sanctions on insider trading increase, we should observe a reduction in insider trading as the expected net benefit (profitability) of insider trading decreases. Second, assuming that regulatory changes have any impact on insider's behaviors, we should also observe a reduction in the volume of insider transactions, that is, the volume of shares traded. ${ }^{31}$

${ }^{29}$ See Eugene F. Fama, Efficient Capital Markets: A Review of Theory and Empirical Work, 25 J. Fin. 383 (1970) and Eugene F. Fama, Efficient Capital Markets II, 46 J. Fin. 1575 (1991).

${ }^{30}$ Standard theory of finance distinguishes between three forms of informational efficiency: the weak form, the semi-strong form, and the strong form. The weak form refers to past information while the semi-strong form refers only to all publicly available information. Generally, empirical evidence supports the weak and semi-strong forms of efficiency suggesting that publicly available information is reflected in the current market price.

${ }^{31}$ Those assumptions are derived from the standard economic theory of crime and punishment. See Gary S. Becker, Crime and Punishment: An Economic Approach, 76 J. Pol. Econ. 169 (1968). Put in simple terms, such a theory argues that the "supply" of crime (in the present case, the amount of insider trading) is negatively related to the expected costs of committing crimes (those expected costs depend mainly of the probability of being caught and the amount of punishment incurred by the criminal if convicted). Given this negative relationship, the theory predicts that the supply of crime will decrease if either the probability of 
Most of empirical studies assessing regulation effectiveness focus on the 1980s because they are characterized by significant increases in the level of enforcement of insider-trading regulations and sanctions against insider trading and, hence, are more likely to affect insider's trading behaviors. As Haddock and Macey report "from January 22, 1982, through August, 29, 1986, the SEC initiated seventy-nine 10b-5 cases, an average of 17.2 per year, which represents a more than sixfold increase in the rate of enforcement". ${ }^{32}$ In addition, the percentage of cases brought against corporate insiders alone went from 49 to 80 percent.

Seyhun developed a broad study over a period extending from 1975 to 1989 measuring "the effects of increases in the level and enforcement of insider-trading regulation on corporate insiders". ${ }^{33} \mathrm{He}$ examines open-market sales and purchases of registered insiders in NYSE, AMEX, and OTC firms and the fifteen-year sample is subdivided in three regulatory periods: the pre-Chiarella period (January 1975 - March 1980) during which the then-doctrine was the parity-of-information doctrine; pre-Insider

being caught or the amount of punishment increases. Therefore, when related to the issue of insider trading, in theory, as insider trading laws have increased the sanctions against insider trading; we should observe a reduction in supply of insider trading. Also, since given that regulatory authorities rely upon circumstantial evidence to detect and prosecute insider trading, we should also anticipate a reduction in insider trading volume as larger transaction volumes raise the probability of being detected and prosecuted for insider trading.

${ }^{32}$ See David D. Haddock and Jonathan R. Macey, Regulation on Demand: A Private Interest Model, with an Application to Insider Trading Regulation, 30 J. L. \& Econ. 311, 333 (1987).

${ }^{33}$ See H. Nejat Seyhun, The Effectiveness of the Insider-Trading Sanctions, 35 J. L. \& Econ. 149 (1992). 
Trading Sanctions Act of 1984 (ITSA) ${ }^{34}$ period (April 1980 - August 1984) during which the then-doctrine was the fiduciary-duty doctrine; and the post-ITSA period (September 1984 - December 1989), which is characterized by both an increased enforcement and increased sanctions. Seyhun performs two sets of tests. First, he tests the effectiveness of insider-trading sanctions in the aggregate. Second, he tests the effects of case law on insider trading prior to earnings announcements and on insider trading prior to takeover announcements. ${ }^{35}$

For the aggregate sample, Seyhun finds that the profitability of insider-trading activity increased by 3.5 percent over the three periods. Contrary to theory's predictions, insider trading is the most profitable during the period with the higher enforcement and sanctions. For example, between 1984 and 1989, insiders' estimated average abnormal profit, after twelve months, was 7 percent while, between 1975 and 1980, their estimated average abnormal profit was 3.5 percent after twelve months. ${ }^{36}$ However, when insiders' transactions are separated in purchases and sales over the three periods, Seyhun observes that:

Overall, [the] evidence indicates that in the 1980s insiders have increasingly shifted to a strategy of bailing out before bad news rather than buying on goods news. ${ }^{37}$

However, this evidence does not change the overall conclusion regarding insidertrading profitability. As a year-to-year analysis shows, "there are no measurable declines

\footnotetext{
${ }^{34}$ Insider Trading Sanctions Act of 1984, Pub. L. No. 98 376, 98 Stat. 1264 (1984).

${ }^{35}$ See after for a discussion of the second set of tests.

${ }^{36}$ See Seyhun, supra note 33, at 158-159 and Table 2.

${ }^{37}$ Id. at 162 .
} 
in either frequency or profitability of insider-trading activity immediately following increases in the level of enforcement of insider-trading sanctions". ${ }^{38}$

Moreover, Seyhun tests the assumption that increases in enforcement and sanctions reduce the volume of insider trading. Overall, Seyhun reaches the same conclusion as the one regarding insider-trading profitability: "insiders have increased their trading activity in the 1980s in spite of increased sanctions. The greater insider-trading activity appears to mirror the growth in the market's overall trading volume. There is no evidence to suggest that increased regulations deterred insiders from trading". ${ }^{39}$

Finally, Seyhun attempts to determine whether regulatory changes had a temporary deterrent effect by examining potential changes in insider-trading activity around (i) March 1980, when the Chiarella decision was announced; (ii) August 1984, when ITSA was signed into law; and (iii) November 1988, when the Insider Trading and Securities Fraud Enforcement Act (ITSFEA) $)^{40}$ was signed into law. The results show that "none of the three events were associated with declines in insider-trading activity. Instead, data suggest that insiders appeared not to be concerned with changes in statutes even on a temporary basis". ${ }^{41}$

\footnotetext{
${ }^{38}$ Id. at 162 and Table 4.

${ }^{39}$ Id. at 169 and Table 7.

${ }^{40}$ Insider Trading and Securities Fraud Enforcement Act of 1988, Pub. L. No. 100-704, 102 Stat. 4677 (1988).

${ }^{41}$ See Seyhun, supra note 33, at 170-171 and Table 8.
} 


\subsection{Insider Trading around Major Corporate Events}

Bettis, Ducan, and Harmon provide a survey of empirical studies analyzing insider trading around major corporate events. ${ }^{42}$ These studies do not investigate the impact of the regulations or regulatory changes on insider trading per se. Rather they study whether or not insiders trade on inside information around major corporate events.

Traditionally, major corporate events are closely followed and monitored by regulatory authorities such as the SEC because it is often around those events that major transactions and price changes occur. More particularly, given that fighting insider trading has become a major priority in SEC's agenda, we should expect that registered insider transactions would be under greater scrutiny around those events. Therefore, if insider trading laws were completely effective, insider activities around those events would cease. ${ }^{43}$

The empirical evidence reviewed by Bettis et al. shows that, despite regulation, insiders continue to realize significant gains from nonpublic information. Not only do insiders continue to purchase shares before "good news" and sell shares before "bad news" but, actually, their trading volume has increased over time. The magnitude of abnormal returns realized or losses avoided also show that insiders trade on the basis of inside information.

\footnotetext{
${ }^{42}$ See J. Carr Bettis, William A. Ducan, and W. Ken Harmon, The Effectiveness of Insider Trading Regulations, 14 J. Applied Bus. Res. 53 (1998) and Appendix.

${ }^{43}$ Id. at 62.
} 
The preponderance of empirical evidence leads the authors to the conclusion that "the legal and regulatory prohibitions have not been completely effective in preventing insiders from trading using their inside information". ${ }^{44}$

There are other studies that expressly analyzed the impact of regulations, and in particular, the increases of level and enforcement of prohibitions on insider trading around major corporate events.

Performing a second set of tests, Seyhun analyzes the impact of case law on insiders' trading prior earnings and takeover announcements. ${ }^{45}$ Looking at the impact of case law, first, he examines "to which extent insiders exploit the upcoming earnings information during the three subperiods". ${ }^{46}$ He examines insider-trading activity during the thirty days preceding the earnings announcement day and whether the net number of transactions was in the same direction as the earnings surprise. He observes a decrease in insiders' exploitation of the upcoming earnings information through time. Prior to 1980, there was timely insider-trading activity in 12 percent of earning announcements months while, in the third period, timely insider-trading activity was in 9.3 percent of earning announcements months. Moreover, it also appears that the timely net number of transactions has also declined from an average of 0.29 transactions per month in the first subperiod to 0.22 transactions per month in the third subperiod. Therefore, Seyhun concludes that "in spite of the significant increases in insider-trading activity over time, insiders in fact became more reluctant to engage in timely trading before earnings

\footnotetext{
${ }^{44}$ Id. at 65.

${ }^{45}$ See Seyhun, supra note 33, at 171-175.

${ }^{46}$ Id. at 171.
} 
announcements during the third subperiod. This evidence suggests that case law provided a measurable constraint on insider-trading activity immediately before earnings announcements". ${ }^{47}$

He also investigates the impact of case law on insider trading prior to takeover announcements. ${ }^{48}$ His findings are similar to those regarding insider-trading activity prior to earnings announcements. He finds that insider purchase activity during thirty days preceding the takeover announcement date falls from $14.5 \%$ to $7.1 \%$ over the three regulatory periods. Interpreting these results, he concludes that, with the increasing involvement of the courts, "insiders have become more and more reluctant to trade immediately before takeover announcements". ${ }^{49}$

Arshadi and Eyssell provide a more enlightening study as their analysis investigates the impact of regulatory changes on insider trading activity in target firms prior to tender offers. $^{50}$ Arshadi and Eyssell observe that the increase of stringent penalties and enforcement activities by the SEC and the Department of Justice has significantly affected the patterns of reported trading by registered insiders prior to tender offer announcements.

\footnotetext{
${ }^{47}$ Id. at 173.

${ }^{48}$ Id. at $173-175$.

${ }^{49}$ Id. at 175 , emphasis added.

${ }^{50}$ See Nasser Arshadi and Thomas H. Eyssell, The Law and Finance of Corporate Insider Trading: Theory and Evidence 87-117 (1993). See also Nasser Arshadi and Thomas H. Eyssell, Regulatory Deterrence and Registered Insider Trading: The Case of Tender Offers, 20 Financial Management, 30 (1991), for the examination of the impact of the ITSA of 1984 on registered insider trading in target firms' shares. See Appendix for more details.
} 
Their sample consists of 553 NYSE and AMEX firms that were targets of tender offers between January 1, 1976, and December 31, 1990. ${ }^{51}$ They develop their sample by examining each issue of the SEC News Digest published during the sample period and retrieving all firms listed as targets in tender offer announcements filings. From this sample, they eliminate 1) firms not on the 1990 CSRP daily returns tape, 2) self-tenders, 3) subsequent bids in multiple-bid contests, and 4) firms that were mentioned in either The Wall Street Journal in a takeover-related context, or for which 13D filings were announced in The Wall Street Journal in the 60-day period preceding the tender offer announcement. ${ }^{52}$ Their study covers five regulatory periods, which are defined by five major events in the history of insider trading legislation and prosecution. These five major events are the Amendment of the Section 32 of the Securities Exchange Act of 1934 in the financial penalties and sanctions faced by insiders are increased (June 1975); the amendment to the Securities Exchange Act of 1934 and the passage of the Rule $14 \mathrm{e}(3)$ prohibiting transactions based on non-public information about impending tender offers by anyone inside or outside of the firms involved (September 1980) ${ }^{53}$; the passage of the Insider Trading Sanctions Act of 1984 (August 1984); the prosecutions of Dennis Levine, Ivan Boesky, and Martin Siegel (May 1986); and the passage of the Insider Trading and Securities Fraud Enforcement Act of 1988 (November 1988).

Analyzing transactions of registered insiders, Arshadi and Eyssell observe that the volume of insider trading prior to tender offer announcement significantly fell over time

\footnotetext{
${ }^{51}$ Data on registered insiders' transactions in their study comes from the ORS database.

${ }^{52}$ Arshadi and Eyssell, supra note 50, at 92.

${ }^{53} 17$ C.F.R. $\S 240.14 \mathrm{e}-3$.
} 
and, particularly, after the passage of ITSA in $1984 .{ }^{54}$ In post-ITSA periods, registered insiders are, on average, net sellers in periods immediately preceding tender offer announcements while in pre-ITSA periods, they were, on average, net purchasers.

On the other hand, Arshadi and Eyssell observe that the cumulative average abnormal returns (CAR) for the sample firms in each of the regulatory periods are not consistent with the fact that registered insiders' preannouncement trading has dramatically declined through time. ${ }^{55}$ They report that, by the announcement date, higher CAR $(28.96 \%$ and $32.35 \%$ ) are observed in periods of broader and more severe anti-insider trading regulation (post-Levine et al. prosecutions and post-ITSFEA periods) in comparison with periods of less regulation (respectively, $27.55 \%$ and $17.2 \%$ for the periods pre-ITSA). Computing CAR over four intervals of event days before announcement day $((-10,-1),(-$ $5,-1),(-2,-1)$, and (0)) and across regulatory periods, they find that CAR in periods of intensive regulation and enforcement (periods post-Levine et al. prosecutions), without exception, are higher than in the other periods. All CAR are statistically significant at the ten percent level or better. Similarly, comparisons of inter-period differences in cumulative abnormal returns suggest that abnormal returns in later periods exceed those in earlier ones (all values are statistically significant). However, few differences exist in inter-period comparisons between periods of stringent regulations and periods where insider trading is less regulated. Investigating the magnitude of excess volumes preceding the announcement in each regulatory period, they find that excess preannouncement volumes in target firms' shares persist in spite of increasing severe legislations and

\footnotetext{
${ }^{54}$ Arshadi and Eyssell, supra note 50, at 104-106.

${ }^{55}$ Id. at $97-104$.
} 
aggressive enforcement by the regulatory authorities (volume coefficients are positive and statistically significant in every regulatory period). ${ }^{56}$ Inter-period volume comparisons show that the net daily share volume rises across time except for the last regulatory period where it slightly decreases. In general, evidence suggests that preannouncement run-ups in target firm share prices are associated with run-ups in the total volume of shares traded, which is, as previously seen, a contradiction with the fact that registered insider trading volume prior to tender offer announcements has declined with increasing stringent penalties and enforcement by regulatory authorities.

However, as Arshadi and Eyssell observes:

Unfortunately, these results so far are aggregated in the sense that they deal with total returns and transactions volume. As such, they say little about who is (or is not) engaging in preannouncement trading. ${ }^{57 * * *}$

To determine the source in such inconsistency, the authors attempt to separate the transactions of registered insiders from those of unregistered insiders. Their results show that the increase in transactions volume over the period analyzed is not explained by transactions from registered insiders at least in the three last regulatory periods. Arshadi and Eyssell find the increase in informed transactions is due to unregistered insiders. However, since insider trading by outside-insiders is almost impossible to observe because they are not required to register their transactions, Arshadi and Eyssell have to develop a series of tests to draw some inferences about the behavior of unregistered insiders. These tests allow them to conclude that the existence of persistent patterns of

\footnotetext{
${ }^{56}$ Id. at 101-104.

${ }^{57}$ Id. at 104.
} 
preannouncement abnormal returns and increasing share volume despite regulatory changes by the existence of outside insider trading.

Given the screening of their sample, first, they attribute a low likelihood to the explanation advanced by Jarrell, Brickley, and Netter that preannouncement price and volume increases may be the result of the workings of a perfectly legal market for information..$^{58}$

Second, they investigate a second possible explanation according to which preannouncement price and volume increases may be the result of successful prediction by market professionals acting on publicly available economic and financial information that a given firm will become a takeover target. In order to test the robustness of this assumption, they replicate Palepu's takeover prediction model and apply it to a portion of their own sample..$^{59}$

${ }^{58}$ See Gregg A. Jarrell, James A. Brickley, and Jeffry M. Netter, The Market for Corporate Control: The Empirical Evidence Since 1980, 2 J. Econ. Perspectives 49, 53 (1988). See Arshadi and Eyssell, supra note $50,106$.

${ }^{59}$ See Krishna G. Palepu, Predicting Takeover Targets, 8 J. Accounting \& Econ. 3 (1986). The model developed by Palepu arises from his observation that 1970s studies claiming that acquisition targets can be accurately predicted by models using public data are in contradiction with the observation that "the stock market does not seem to predict acquisition targets with a high degree of accuracy even three months prior to the announcement of takeover bids". He argues that this contradiction is explained by the fact that the methodology used by the earlier acquisition studies suffers from "three principal methodological flaws, which make their reported prediction accuracies unreliable". Palepu develops a takeover prediction model that avoids these biases resulting from these methodological flaws. In his model, Palepu uses a probability model (binomial logit model) "to specify the exact functional relationship between the firm characteristics and its acquisition likelihood in a given period." The independent variables are selected on the basis of a set 
They find that the takeover prediction model could correctly identify only $42.9 \%$ of actual targets as such and misclassified $31.7 \%$ of the non-target firms as targets. They conclude that the explanatory power of the estimated model is quite small. Therefore, Arshadi and Eyssell contend that the existence of persistent patterns of preannouncement abnormal returns and increasing share volume despite regulatory changes cannot be explained by successful predictions by market professionals acting on publicly available economic and financial information. ${ }^{60}$

Pursuing their analysis of the hypothesis that takeover prediction may explain these increases of preannouncement price and volume, CAR for each group for 250-day period ending on the last of the prediction day are calculated in four portfolios: 1) all firms predicted as targets by the model, 2) actual target firms correctly identified by the model, 3) all firms not predicted as targets by the model, and 4) actual targets not predicted as such by the model. They argue that large CAR in actual target firms $(38.75 \%$ for targets

of six hypotheses, "frequently suggested in the academic and/or popular financial literature, on the types of firms that are likely to become acquisition targets." Instead of using a simple maximum likelihood (MLE) procedure to estimate the model parameters and the state probabilities, he uses a conditional maximum likelihood estimator (CMLE). The prediction ability of the model is tested on a large group of firms at a given time in order to make the prediction test sample resemble the population as closely as possible. Finally, instead of using an arbitrary cutoff probability of 0.5 as traditionally used in earlier acquisition prediction studies, he uses the optimal cutoff probability to test the possibility of earning excess returns by investing in potential targets identified by the model. His findings are that "while the estimated model is found to be statistically significant, its explanatory power is quite small." He finds that "the estimated model's ability to predict targets is not superior to that of the stock market." His conclusion is that the model does not predict targets accurately.

${ }^{60}$ Arshadi and Eyssell, supra note 50, at 113. 
classified correctly and $40.84 \%$ for targets classified incorrectly) could only have been predicted in possession of an accurate takeover prediction model, which is not the case according to their previous robustness test of Palepu's model. As they explain, if one uses Palepu's model to classify firms, only two portfolios will be used: 1) one group of predicted targets and 2) one group of predicted non-target firms. When they calculate excess returns in each portfolio (each portfolio includes both actual and misidentified targets), CAR are $-4.44 \%$ and $-6.14 \%$ respectively for each portfolio. These results confirm their previous conclusion (and Palepu's ones) that "the model does not provide economically useful predictions" and that observed persistent patterns of preannouncement excess returns through time cannot be explained by the use of a takeover prediction model. ${ }^{61}$

Finally, to strengthen their theory that the use of inside information by outsideinsiders explains the existence of persistent patterns of preannouncement abnormal returns and increasing share volume despite the increase in regulation, they investigate inside-insider volume as a proportion of total daily share volume for each regulatory period. As expected, the results show that net inside-insider purchases as a proportion of total share volume fall over time $(1.54 \%$ in the first regulatory period to $-0.412 \%$ in the last regulatory period). After the passage of ITSA (regulatory period 3), registered insiders participate less prior to tender offer announcements. These results are consistent with the hypothesis that increasing regulations have deterrent effects on registered insider-trading activity. These latter results strongly enhance Arshadi and Eyssell's theory

\footnotetext{
${ }^{61}$ Id. at 113.
} 
that outside-insider trading explains the existence of persistent patterns of abnormal returns and increasing share volume in spite regulatory changes.

Their conclusions are consistent with Seyhun's. Increasingly stringent regulations and a vigorous regulatory attitude by the SEC and Justice Department have significantly altered registered insiders' behavior, particularly around corporate events which are subject to greater scrutiny by the regulatory authorities.

However, as we argued above, this does not mean that insider trading per se has been eliminated as the existence through time of persistent patterns of abnormal returns and increasing share volume shows. Actually, it seems to have shifted from registered insiders to unregistered insiders (outside-insiders). As Seyhun did, Arshadi and Eyssell conclude that insider-trading regulation is overall ineffective in preventing trading on the basis of inside information. ${ }^{62}$

Seyhun and Bradley investigate insider trading preceding corporate bankruptcy announcements. ${ }^{63}$ Contrary to previous empirical studies ${ }^{64}$, they find that insiders do "bail out" on their stockholders prior to filing a bankruptcy petition. Actually, it appears that insiders begin to sell five years before the filing date and insiders' selling volume increases up to the announcement month. Moreover, in contrast to their predecessors,

\footnotetext{
${ }^{62}$ Ibid. at 117.

${ }^{63}$ H. Nejat Seyhun and Michael Bradley, Corporate Bankruptcy and Insider Trading, 70 J. Bus. 189 (1997).

${ }^{64}$ See Appendix.
} 
Seyhun and Bradley look at the impact of regulatory changes on this type of insider trading. ${ }^{65}$

They first observe that the securities of firms that file bankruptcy petitions suffer significant losses in the years preceding the filing date. For example, in the second year before filing, the price of their shares dropped an average of $17 \%$. In the year before, investors lost another $48 \%$ and in the month of filing, they lost another $28 \%$. Over the 2year period before filing, the average cumulative loss amounts to $70 \%$. Regarding the average abnormal loss for each year during the four years before filing, they are respectively $14 \%, 18 \%, 39 \%$, and $66 \%$. In the month of filing, the average abnormal loss amounts to $30 \%$. Over the five year period before the filing date, the average abnormal loss reaches $206 \%$.

When looking at registered insider trading prior to bankruptcy petition filing, Seyhun and Bradley find that "insiders are significant net sellers of their firm's shares in the months and years preceding a bankruptcy filing." They observe that, in the fifth year before filing a bankruptcy petition, insider selling represents a total disinvestment of $\$ 716,000$ per firm. When compared with the fact that the returns to the stockholders of these firms are significantly negative in the fourth year before filing, the data suggest that "insiders possess privileged information regarding the future price of their firms' securities". ${ }^{66}$ Moreover, they observe that the trading pattern by top executives and officers shows that they have more information regarding their firms' future situation than

\footnotetext{
${ }^{65}$ As explained by Seyhun and Bradley, this may partially explain why these previous empirical studies did not find that corporate managers do sell their insider holdings prior to filing a bankruptcy petition.

${ }^{66}$ Seyhun and Bradley, supra note 63, at 201.
} 
other insiders. Top executives are net sellers in every period and officers are net sellers in four of the five periods.

Investigating the relationship between the timing of insider trading and security returns, Seyhun and Bradley find that insiders avoid the significant capital losses incurred by stockholders of bankrupt firms in the years before filing the petition by selling before the stock price declines and buying stock after prices have fallen.

After having investigated insider-trading timing and volume in bankrupt firms, Seyhun and Bradley analyze the impact of regulatory changes in the laws governing corporate bankruptcies and insider trading on these variables. Their observations are consistent with Seyhun's observations in his previous studies on the impact of regulatory changes on insider trading around major corporate events, which attract the scrutiny of the regulatory authorities. While we observe that insider selling volume before the filing increased despite an increasingly stringent legal environment, after the passage of the ITSA in 1984 insiders became more reluctant to sell their holdings in the 30 days preceding a filing. Since the passage of the ITSA, they find that "top executives have reported literally no transactions in their firms' shares in the 30 days preceding a filing." In other words, the increases in the level and enforcement of insider-trading regulations did have an impact on insider-trading patterns, which manifest particularly by the fact that insiders avoid trading around events being the object of great scrutiny by the regulatory authorities. However, this does not mean that insider trading has disappeared, as the data show; actually, insiders continue to trade in their own company securities.

Two general observations can be made regarding the effectiveness of insider-trading regulations in deterring insiders from trading on the basis of inside information. First, 
despite the increases in the level and enforcement of insider-trading prohibitions, insiders continue to trade on the basis of inside information. The level of insider trading seems to have dramatically increased. However, it appears that the increase of stringent penalties and enforcement activities by the SEC and the Department of Justice, particularly against insiders trading on the basis of nonpublic information related to major corporate events, had had an impact on corporate insider-trading patterns. Corporate insiders do trade less around major corporate events.

Second, while we do observe that these regulations had an impact on corporate insider-trading patterns, insider trading per se has not been eliminated. Actually, these regulations did nothing more than change the nature of insider trading; they have not eliminated or even reduced it. As Seyhun shows, the nature of insider trading has changed in the sense that (registered) insiders now trade more on inside information not related to major corporate events or at times other than those subject to strict scrutiny by regulators. Furthermore, as Arshadi and Eyssell show, the nature of insider trading has changed in the sense that the vast majority of insider trading is not derived so much from registered insiders whose transactions are under great scrutiny by the regulatory authorities as from unregistered insiders (outside-insiders).

The empirical evidence seems to be consistent with our analysis of the impossibility for the regulation of insider trading to be effective. In the facts, the regulation of insider trading appears largely ineffective in preventing non-public information from circulating in the markets essentially due to the intangible nature of the information. 


\section{Conclusion}

This contribution of this paper was to study whether regulation of insider trading can be effective in deterring insiders from trading on non-public information. Our analysis shows that it is in theory and practice impossible for insider trading regulation to be effective. Because of the intangible nature of the information, insiders have a large variety of ways to escape the regulation of insider trading. Actually, it appears as some of the most recent findings in the empirical literature show that, despite the evolution and increases in enforcement and level of insider trading prohibitions, insider trading and its profitability have become more important. Therefore, we can argue that our analysis is consistent with the empirical literature.

Our conclusions draw some important implications for further empirical research on this issue such as attempting to develop a cost-benefit analysis of the regulation of insider trading. Despite that the regulation of insider trading does not eliminate insider trading, there may be some benefits such as increasing investors confidence, increasing market liquidity, or reducing the cost of capital that result from such regulation. Therefore, empirical research might also be done regarding whether such benefits outweigh the costs of such a regulation. 


\section{APPENDIX}

Survey of the Empirical Literature Pertaining to Corporate Insider Trading and Analysis of Strength of Relationship between Insider Trading and Other Factors and the Magnitude of Abnormal Returns Pertaining to Related Insider Activity

\begin{tabular}{|c|c|c|c|c|c|}
\hline \multicolumn{6}{|c|}{$\begin{array}{l}\text { Panel A } \\
\text { Insider Trading Activity in Target Firms Around Takeover Announcements }\end{array}$} \\
\hline Authors & $\begin{array}{l}\text { Sample } \\
\text { Period }\end{array}$ & Issue Investigated & Evidence Measurement & Strength of Evidence & Magnitude of Abnormal Returns \\
\hline $\begin{array}{l}\text { Keown and } \\
\text { Pinkerton } \\
\text { (1981) }\end{array}$ & $1975-1978$ & $\begin{array}{l}\text { Evaluation of insider activity in the } \\
\text { month before the first announcement } \\
\text { of a takeover. }\end{array}$ & $\begin{array}{l}\text { No evidence of rampant/frantic trading } \\
\text { by corporate insiders of targets firms in } \\
\text { the month before takeover } \\
\text { announcements. }\end{array}$ & $\begin{array}{c}76 \% \text { of the firms studied experienced } \\
\text { no open market purchases or sales in } \\
\text { the month prior to the announcement } \\
\text { date, and only } 12 \% \text { had net positive } \\
\text { market purchases. }\end{array}$ & $\begin{array}{l}\text { Average CAR of } 25.27 \% \text { for the } \\
60 \text { day period prior to the } \\
\text { announcement period. }\end{array}$ \\
\hline $\begin{array}{l}\text { Arshadi and } \\
\text { Eyssell } \\
(1991)^{*}\end{array}$ & $1975-1987$ & $\begin{array}{l}\text { Test null hypothesis that the passage of } \\
\text { ITSA had no effect on the actions of } \\
\text { registered insiders. Preannouncement } \\
\text { trading by registered insiders is at least } \\
\text { as prevalent subsequent to the passage } \\
\text { of the Act as it was before its passage. }\end{array}$ & $\begin{array}{c}\text { Examine the volume and profitability of } \\
\text { registered insider trading in target firms' } \\
\text { shares before and after the passage of } \\
\text { the ITSA of } 1984 .\end{array}$ & $\begin{array}{l}\text { Rejection of the null hypothesis that } \\
\text { the number of net purchases in the } \\
\text { event period is the same as in the } \\
\text { estimation for the firm sample } \\
\text { (Computed test statistic } \mathrm{Z}=3.24 \text { ). } \\
\text { ACNT pre-ITSA }=1.81 \\
\text { ACTN post-ITSA }=-1.67 \\
\text { (statistically insignificant) }\end{array}$ & $\begin{array}{l}\text { CWAPE reaches } 9.89 \% \text { by the } \\
\text { week of the tender offer } \\
\text { announcement in the pre-ITSA } \\
\text { sample. Strong reversal of this } \\
\text { pattern of observed for the post- } \\
\text { ITSA sample. CWAPE reaches - } \\
10.78 \% \text { by the announcement date. }\end{array}$ \\
\hline $\begin{array}{l}\text { Sanders and } \\
\text { Zdanowicz } \\
\text { (1992) }\end{array}$ & $1978-1986$ & $\begin{array}{l}\text { Study examines average abnormal } \\
\text { returns, trading volume and reported } \\
\text { transactions of target firm insiders in } \\
\text { periods preceding takeover } \\
\text { announcements. }\end{array}$ & $\begin{array}{l}\text { Test whether insiders change their } \\
\text { trading activity in the period before the } \\
\text { first public announcement of a takeover } \\
\text { bid (but after they have private } \\
\text { knowledge of the upcoming } \\
\text { announcement). }\end{array}$ & $\begin{array}{l}\text { They conclude that there is no } \\
\text { increase in purchasing during the } \\
\text { time when insiders are informed } \\
\text { about upcoming takeover } \\
\text { announcement. }\end{array}$ & $\begin{array}{c}\text { Average CAR of } 32.41 \% \text { for the } \\
60 \text { day period prior to the } \\
\text { announcement (significant at the } \\
0.01 \text { level). }\end{array}$ \\
\hline $\begin{array}{c}\text { Seyhun } \\
(1992)\end{array}$ & 1975-1989 & $\begin{array}{l}\text { Looks briefly at insider activity before } \\
\text { takeovers }\end{array}$ & $\begin{array}{l}\text { Evaluates (non-statistically) whether } \\
\text { large trading profits made by insiders } \\
\text { were because of trading before takeover } \\
\text { announcements (and/or earnings } \\
\text { surprises). }\end{array}$ & $\begin{array}{c}\text { Found that the proportion of takeover } \\
\text { announcements months (i.e. the } 30 \\
\text { days preceding takeover } \\
\text { announcements) with insider } \\
\text { purchases ranges from } 14.1 \% \text { to } \\
7.4 \% \text { over the over three sub-periods. }\end{array}$ & N/A \\
\hline
\end{tabular}




\begin{tabular}{|c|c|c|c|c|c|}
\hline \multicolumn{6}{|c|}{$\begin{array}{c}\text { Panel B } \\
\text { Insider Trading Activity Before Bankruptcy Announcements }\end{array}$} \\
\hline $\begin{array}{l}\text { Loderer and } \\
\text { Sheehan } \\
(1989)\end{array}$ & $1971-1985$ & $\begin{array}{l}\text { Investigates whether insiders of } \\
\text { bankrupt firms hold less stock or } \\
\text { reduce their holdings compared to } \\
\text { what we observed for insiders of } \\
\text { similar firms that do not go bankrupt. }\end{array}$ & $\begin{array}{l}\text { No much evidence to support the idea } \\
\text { that these insiders do reduce their } \\
\text { holdings. }\end{array}$ & & N/A \\
\hline $\begin{array}{l}\text { Eyssell } \\
(1991)\end{array}$ & 1975-1987 & $\begin{array}{l}\text { Investigates what insiders do before } \\
\text { bankruptcy's and before voluntary } \\
\text { liquidations. }\end{array}$ & $\begin{array}{c}\text { Uses a standardized measure of the net } \\
\text { number of purchases (purchases - sales) } \\
\text { and also does Chi-Square test to look at } \\
\text { differences between insider activity in } \\
\text { the case of bankruptcy versus voluntary } \\
\text { liquidation using purchases and sales } \\
\text { separately. }\end{array}$ & $\begin{array}{c}\text { Net number of purchases analysis } \\
\text { shows significant differences } \\
\text { between the two periods (at the } 0.01 \\
\text { level for voluntary liquidation sample } \\
\text { and } 0.01 \text { level for the bankruptcy } \\
\text { sample). }\end{array}$ & $\begin{array}{l}\text { The per firm average CAR of } \\
16.07 \% \text { for the } 36 \text { months leading } \\
\text { up to the announced voluntary } \\
\text { conversion. CAR of }-39.04 \% \text { for } \\
\text { the same period before a } \\
\text { bankruptcy. }\end{array}$ \\
\hline $\begin{array}{l}\text { Gosnell, } \\
\text { Keown, and } \\
\text { Pinkerton } \\
\text { (1992) }\end{array}$ & $1985-1987$ & $\begin{array}{l}\text { Measure insider trading during the } 31 \\
\text { month period surrounding the first } \\
\text { public announcement of a bankruptcy } \\
\text { filing of OTC firms. }\end{array}$ & $\begin{array}{l}\text { Test using a control sample of firms and } \\
\text { the sample of bankrupt firms. The } \\
\text { relative frequencies of buy and sell } \\
\text { transactions by insiders are compared } \\
\text { between the two groups. }\end{array}$ & $\begin{array}{l}\text { Find that insiders in firms that go } \\
\text { bankrupt do significantly (at the } 0.01 \\
\text { level) more selling the } 18-13 \text { months } \\
\text { and 6-1 months prior to the } \\
\text { bankruptcy announcement.. }\end{array}$ & $\begin{array}{l}\text { Mean losses avoided by insider } \\
\text { sellers of } 27.55 \% \text {. }\end{array}$ \\
\hline \multicolumn{6}{|c|}{$\begin{array}{c}\text { Panel C } \\
\text { Insider Trading Activity Around Other Corporate News Events (e.g. Dividend Announcements) }\end{array}$} \\
\hline $\begin{array}{l}\text { Finnerty } \\
\text { (1976a) }\end{array}$ & 1967-1972 & $\begin{array}{c}\text { Identification of relationship between } \\
\text { insider buying/selling and (1) a large } \\
\text { range of fundamental variables (e.g. } \\
\text { future earnings and future dividends) } \\
\text { and (2) firm characteristics (e.g. firm } \\
\text { size). }\end{array}$ & $\begin{array}{l}\text { Weighted factor coefficients from a } \\
\text { linear discriminant function were used } \\
\text { to evaluate the difference among the } \\
\text { means of the factors. }\end{array}$ & $\begin{array}{l}\text { Very strong evidence of the } \\
\text { relationship between insider trading } \\
\text { activity and the size (significant at } \\
\text { 0.0000), earnings (significant at } \\
\text { 0.0252) and dividends (significant at } \\
\text { 0.0001). }\end{array}$ & N/A \\
\hline $\begin{array}{l}\text { Penman } \\
(1982)\end{array}$ & $1967-1974$ & $\begin{array}{l}\text { Evaluates relationship between insider } \\
\text { trading and the disclosure of } \\
\text { management earnings forecasts, and } \\
\text { measures performance of the insiders } \\
\text { who bought/sold before and } \\
\text { sold/bought after positive/negative } \\
\text { management earnings forecasts. }\end{array}$ & $\begin{array}{l}\text { The relationship between the direction } \\
\text { of the insider activity measures and the } \\
\text { magnitude of abnormal returns was } \\
\text { measured. Also, the magnitude of profits } \\
\text { to the insiders for their trading was } \\
\text { measured. }\end{array}$ & $\begin{array}{c}\text { The direction of insider trading and } \\
\text { magnitude of abnormal return in the } \\
3 \text { days around forecast date was } \\
\text { significant at the } 0.05 \text { level. } \\
\text { Abnormal return associated with } \\
\text { trading activity was significant at the } \\
0.0005 \text { level. }\end{array}$ & $\begin{array}{c}\text { Mean 3-day abnormal returns } \\
\text { ranged from } 1.49 \% \text { to } 14.43 \% \text { for } \\
\text { positive insider trading firms and } \\
\text { from } 1.3 \% \text { to }-9.00 \% \text { for selling } \\
\text { firms. }\end{array}$ \\
\hline
\end{tabular}




\begin{tabular}{|c|c|c|c|c|c|}
\hline $\begin{array}{l}\text { Moss and } \\
\text { Kohers } \\
(1990)\end{array}$ & $1982-1983$ & $\begin{array}{l}\text { Investigates whether insiders buy their } \\
\text { stock prior to favorable earnings and } \\
\text { dividend announcements and hence } \\
\text { abnormal profits. }\end{array}$ & $\begin{array}{c}\text { Used the period from } 2 \text { to } 60 \text { days } \\
\text { before announcements of higher (at least } \\
10 \% \text { different) than expected } \\
\text { earnings/dividends and measured the } \\
\text { return to the insiders. }\end{array}$ & $\begin{array}{l}\mathrm{p} \text {-values for the abnormal return to } \\
\text { insiders for these cases were } \\
\text { significant at levels ranging from } \\
0.036 \text { (where earnings were less than } \\
\text { expected) to } 0.000 \text { (were less than } \\
\text { expected). }\end{array}$ & $\begin{array}{l}\text { ARs ranged from } 34.71 \% \text { when } \\
\text { dividends were greater than } \\
\text { expected to }-350.89 \% \text { when } \\
\text { dividends were less. }\end{array}$ \\
\hline $\begin{array}{l}\text { Allen and } \\
\text { Ramanan } \\
(1990)\end{array}$ & 1977-1981 & $\begin{array}{l}\text { Paper examines the joint effects, both } \\
\text { additive and interactive of the surprise } \\
\text { in annual earnings announcements and } \\
\text { prior levels of insider trading } \\
\text { surrounding earnings announcements. }\end{array}$ & $\begin{array}{c}\text { Used the trading activity in the } 75 \text { day } \\
\text { period(s) before earnings } \\
\text { announcements. Used ANCOVA to test } \\
\text { the main effect between trading activity } \\
\text { and earnings surprise. }\end{array}$ & $\begin{array}{l}\text { Three day abnormal returns } \\
\text { associated with each marginal } \\
\text { trading classification were signed in } \\
\text { accordance with the expected } \\
\text { implications of the signals (e.g. } \\
\text { positive trading would have positive } \\
\text { abnormal returns). }\end{array}$ & $\begin{array}{c}\text { Insider purchase activity yielded } 3 \\
\text { day CAR of } 1.38 \% \text { on average. } \\
\text { CAR during }+2 \text { to }+20 \text { day period } \\
\text { were } 1.25 \% \text {. }\end{array}$ \\
\hline $\begin{array}{c}\text { John and } \\
\text { Lang (1991) }\end{array}$ & $1975-1985$ & $\begin{array}{l}\text { Look at net measures of insider trading } \\
\text { activity as signaling that is relevant for } \\
\text { future dividend announcements. }\end{array}$ & $\begin{array}{l}\text { Test using various regressions between } \\
\text { abnormal (excess) returns on/around } \\
\text { dividend announcement dates and } \\
\text { various insider trading measures. }\end{array}$ & $\begin{array}{l}\text { Insider trading prior to the } \\
\text { announcement has significant } \\
\text { explanatory power for the returns } \\
\text { that are present on the dividend } \\
\text { announcement date. }\end{array}$ & $\begin{array}{l}\text { 1-day AR for the insider selling } \\
\text { group is about } 2.2 \% \text { less than group } \\
\text { with dividend announcements. }\end{array}$ \\
\hline $\begin{array}{l}\text { Park, Jang, } \\
\text { and Loeb } \\
\text { (1995) }\end{array}$ & 1986-1987 & $\begin{array}{l}\text { Investigate the trading behavior of } \\
\text { insiders surrounding the release of } \\
\text { earnings information. }\end{array}$ & $\begin{array}{c}\text { Looked at changes in insider activity in } \\
\text { the period preceding EPS } \\
\text { announcements. } \\
\text { Also investigated the actual profit (loss) } \\
\text { earned by insiders after their } \\
\text { purchases/sales. }\end{array}$ & $\begin{array}{l}\text { Found significant decreases in } \\
\text { purchasing activity before earnings } \\
\text { announcements, but there are } \\
\text { significant increases in selling before } \\
\text { bad news announcements. } \\
\text { Differences between purchases and } \\
\text { sales are highly significant in all } \\
\text { cases. }\end{array}$ & $\begin{array}{c}\text { Mean abnormal profits to insiders } \\
\text { who bought from - } 50 \text { to }-26 \text { days } \\
\text { before earnings announcement of } \\
\text { 5.8\%. Abnormal profits exceed } 8 \% \\
\text { for good news firms. }\end{array}$ \\
\hline
\end{tabular}

*Study that does not appear in the original survey by Bettis, Duncan, and Harmon (1998).

Source: J. Carr Bettis, William A. Ducan, and W. Ken Harmon, The Effectiveness of Insider Trading Regulations,

14 J. Applied Bus. Res. 53 (1998) 